\title{
Distribution and population dynamics of the rock shrimp Sicyonia ingentis and Sicyonia penicillata (Decapoda: Sicyoniidae) in the Gulf of California
}

\author{
Juana López-Martínez ${ }^{1}$, Carlos H. Rábago-Quiroz ${ }^{2}$, Edgar A. Arzola-Sotelo ${ }^{1}$ \\ Rufino Morales-Azpeitia ${ }^{1} \&$ Alejandro Acevedo-Cervantes ${ }^{3}$ \\ ${ }^{1}$ Centro de Investigaciones Biológicas del Noroeste, S.C. Unidad Sonora \\ Campus Guaymas, Guaymas, Sonora, México \\ ${ }^{2}$ Instituto Nacional de Pesca y Acuacultura, Centro Regional de Investigación Acuícola y Pesquera \\ La Paz, Baja California Sur, México \\ ${ }^{3}$ Instituto Tecnológico de México, Guaymas, Sonora, México \\ Corresponding author: Juana López-Martínez (jlopez04@ cibnor.mx)
}

\begin{abstract}
Aspects of distribution and population dynamics were assessed in two rock shrimp species of the genus Sicyonia. Samples were obtained by sea bottom trawling in depths from 50 to $460 \mathrm{~m}$ during two research cruises on board the B/I BIP XII in the Gulf of California, Mexico. Taxonomic identification of specimens was performed; measurements of individual length and weight data were taken to obtain biometric relationships and length frequencies. Growth parameter estimations were performed adjusting the von Bertalanffy growth model (VBGM), and the recruitment pattern was obtained by the ELEFAN II method. Longevity was estimated with the Taylor equation, natural mortality with six different models, and length at first maturity by the logistic model. A total of 67 fishing trawls were monitored, and 1,330 specimens were caught $(65 \%$ S. ingentis; $35 \% \mathrm{~S}$. penicillata) in the depth range from 124 to $338 \mathrm{~m}$. Sex ratio (F:M) was 1.0:1.6 for both species; weight and length relationships (both sexes) showed an isometric growth for $S$. ingentis and positive allometric growth for S. penicillata. Growth parameters and longevity values were moderate (1.71 and 1.81 years) with age at first maturity around six months for both species. The recruitment pattern showed continuous periods all year long, with a notable peak from November to May. Average natural mortality was 2.47 for $S$. ingentis and 2.35 for $S$. penicillata. Distribution and population dynamics information reported in this study for these two shrimp species should be considered as base knowledge in subsequent studies on fisheries management in the Gulf of California.
\end{abstract}

Keywords: Sicyonia; recruitment; growth; natural mortality; population dynamics; Gulf of California

\section{INTRODUCTION}

Shrimps of the family Sicyoniidae (Ortmann, 1898) are benthic penaeids comprising the monotypic genus Sicyonia (H. Milne-Edwards, 1830) with more than 52 species globally distributed (Pérez-Farfante \& Kensley, 1997; Crosnier, 2003). This shrimp genus is distributing predominantly in tropical and subtropical waters in depths from few meters to nearly $1,000 \mathrm{~m}$ (Shanis et al., 2013; Patania \& Mutlu, 2015). Sicyonia shrimps had been discarded from the large commercial catches of penaeid shrimps made in tropical and subtropical waters of the eastern Pacific and western Atlantic oceans because of their hard exoskeleton, commonly thought both consumers and processing indus- try would reject them. Nonetheless, increased demand for shrimp encouraged fisherman and dealers to bring the larger species to market (Kennedy et al., 1977; Pérez-Farfante, 1985; López-Martínez et al., 1999a, 2002a; Stiles et al., 2007).

Sicyonia spp. also primarily targeted in the south Atlantic (specifically Florida, USA), accounted for a smaller percentage of landings (1.8 million $\mathrm{lb} ; 816,000$ $\mathrm{kg}$ ) valued at US\$2.5 million (Kennedy et al., 1977; Bauer, 1992; Bauer \& Rivera-Vega, 1992; NMFS, 2003). In the eastern Pacific, there was an intent to commercialize this shrimp (small scale) in the northern Pacific from Peru (Arana \& Méndez, 1978), in the Gulf of California (Hendrickx, 1984, 1995; López-Martínez et al., 2002a,b) and in the eastern coast of Baja

Corresponding editor: Ingo Wehrtmann 
California, particularly Bahía Magdalena, Baja California Sur, Mexico (Mathews \& González, 1975). However, exploration and location of new resources with fishery potential, as in the case of Sicyonia shrimps, required research on the biology, distribution, population structure and adequate catch technology to generate information to plan sustainable management (Quinn \& Deriso, 1999). Population dynamics information has been poor for Sicyonia genus (LópezMartínez et al., 2002a,b; Nunes-Pralon, 2012; De Camargo-Silvestre, 2015).

In the American Pacific coasts, Sicyonia shrimps are widely distributed (Pérez-Farfante, 1985; Hendrickx, 1995). Twelve species of this genus have been reported for the eastern Pacific Ocean (Pérez-Farfante \& Boothe, 1981; Hendrickx, 1995); the majority of which, similar to their conspecifics of the western Atlantic Ocean, are distributed from 40 to $630 \mathrm{~m}$ in depth, usually on coarse sand bottoms (Freitas, 1984; Sunada \& Richards, 1992). In Mexico, particularly in the Gulf of California, nine species of the genus Sicyonia have been reported: S. ingentis (Burkenroad, 1938), S. disparri (Burkenroad, 1934), S. disedwardsi (Burkenroad, 1934), S. penicillata Lockington, 1879, S. picta Faxon, 1893, S. aliaffinis (Burkenroad, 1934), S. disdorsalis (Burkenroad, 1934), S. martini PérezFarfante \& Boothe, 1981 and S. laevigata Stimpson, 1871 , of which $S$. disparri is endemic to the region (Hendrickx, 1984).

In the Gulf of California region, several studies about genus Sicyonia have reported different aspects, such as: taxonomy (Hendrickx, 1984; Pérez-Farfante, 1985), geographic and bathymetric distribution (Freitas, 1984; Sunada \& Richards 1992; Hendrickx, 1996, 2002; Estrada-Ramírez \& Calderón-Aguilera, 2001), reproductive biochemical behavior (Anderson et al., 1985; Bauer, 1992; López-Martínez et al., 1999a), morphometric relationships (Hendrickx, 1984) and potential fishery analysis (Cobb et al., 1973; ArreguínSánchez, 1981; López-Martínez et al., 1999b, 2002a,b).

Despite the studies previously mentioned, little information is found related to the population dynamics of these species. Therefore, the objective of this study was to determine latitudinal and bathymetric distribution, sex ratio, weight and length relationship, growth, natural mortality and recruitment pattern of $S$. ingentis and S. penicillata, which are the most abundant rock shrimp species in the Gulf of California (Hendrickx, 1996; López-Martínez et al., 1999b, 2002a,b).

\section{MATERIALS AND METHODS}

\section{Study area and sampling}

Samples were obtained in depths from 50 to $460 \mathrm{~m}$ during two prospective cruises in 2007 (June 3-20;
October 16-20) on board B/I BIP XII in the Gulf of California, Mexico, between $30^{\circ} 59^{\prime} \mathrm{N}, 114^{\circ} 19^{\prime} \mathrm{W}$, and $26^{\circ} 07^{\prime} \mathrm{N}, 109^{\circ} 55^{\prime} \mathrm{W}$ off Sonora and Sinaloa (Fig. 1).

For fishing operations, a polyethylene bottomtrawling net was used with $40 \mathrm{~mm}$ mesh opening, 38/34 $\mathrm{m}$ in length, mouth perimeter of $68 \mathrm{~m}$ and upper headline of $38 \mathrm{~m}$. Following a systematic sampling (Thompson, 1991), fishing trawls were made in each sampling point with one hour of effective trawling at an average speed of $5 \mathrm{~km} \mathrm{~h}^{-1}$.

In each trawl, a $20 \mathrm{~kg}$ sample was taken at random and preserved frozen until processing in the laboratory. Data related to each throw were recorded, such as depth and geographic coordinates with an echo sounder and a geographical position satellite (GPS). In the Fisheries Laboratory of Centro de Investigaciones Biológicas del Noroeste, the specimens of the family Sicyoniidae were identified to species following the dichotomous identification keys of Hendrickx (1984), Pérez-Farfante (1985) and Fischer et al. (1995). Reference samples were fixed with formaldehyde at $10 \%$ and later preserved in ethyl alcohol at $70 \%$.

\section{Biometrics and sex ratio}

For both species, each specimen was measured in total length (TL) and weight (TW) (TL $0.1 \mathrm{~g}$ precision and TW, $0.1 \mathrm{~g}$ precision, respectively). Sex ratio was determined (F: female, M: male), as well as the weight/length relationship (for both sexes) using the potential model: $W=a(T L)^{b}$; where $W$ : individual weight in $\mathrm{g}, T L$ : total length in $\mathrm{mm}, a$ : regression constant, and $b$ : regression coefficient (Ricker, 1975). This $b$ coefficient was statistically evaluated by the Student- $t$ test (Zar, 1984) to determine growth type and confidence intervals $(95 \%)$ for each species. A regression coefficient $b$ equal to 3 (statistically) indicates that the species present an isometric growth, that is, a proportional growth in length and weight of individuals. On the other hand, if $b \neq 3$ an allometric growth is presented by the species, suggesting a differential or disproportional growth of length and weight. When $b<3$ the species shows a negative allometric growth (a preferential increase of length more than weight) and if $b>3$, it indicates a positive allometric growth (a preferential increase of weight more than length) for the species (Gould, 1966; Gopalakrishnan et al., 2014).

\section{Latitudinal and bathymetric distribution of the species}

Geographic coordinates and sampling depth of each fishing trawl were used to map species distribution and establish bathymetric ranges. 

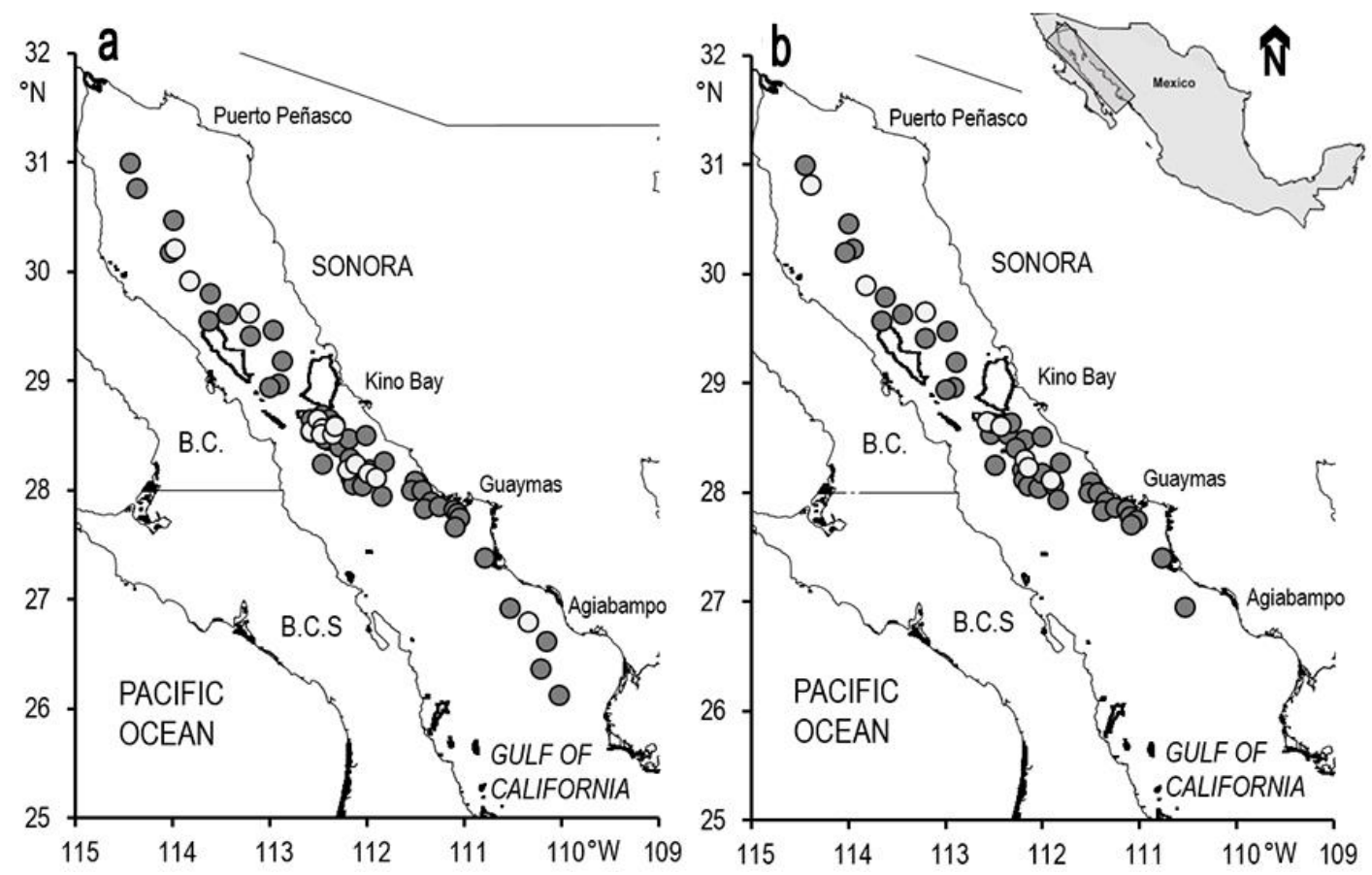

Figure 1. Distribution of: a) Sicyonia ingentis, and b) Sicyonia penicillata caught during the two 2007 cruises in the Gulf of California (white circles= positive captures and grey circles= negative captures).

\section{Individual growth and recruitment pattern}

Size frequency of each species was obtained in $5 \mathrm{~mm}$ intervals (males, females and both sexes), and due to the few specimens for each species in the samples, the combined sex size frequency was used to estimate growth through the von Bertalanffy growth model (VBGM) (Von Bertalanffy, 1938). The VBGM function is: $L_{T}=L_{\infty}\left(1-\mathrm{e}^{-K(t-t)}\right)$, where $L_{T}$ : total length at time $t ; L_{\infty}$ : asymptotic total length; $K$ : instantaneous growth coefficient; and $t_{0}$ : hypothetical age when the specimens had an average length of zero (Hilborn \& Walters, 1992).

Powell (1979) and Wetherall et al. (1987) methods were used for estimating input values for the $L_{\infty}$ parameters. In population dynamic's studies, it is common that when individual growth estimates are made with specimen's size data, a series of size frequencies is available over time. In case of only having samples from one or several surveys (as in this case), structure simulation is used; it is achieved by repeating the sample for an adequate time course, assuming that all cohorts follow the same growth curve, commonly known as a system of constant parameters (Sparre \& Venema, 1995; Palomares \& Pauly, 2008). A cohort is defined as a species group of specimens born at the same time and space. Once this simulation is performed, the Shepherd's Length Composition Analysis and NSLCA methods were used to estimate
$L_{\infty}$ and $K$. The final estimates were obtained with electronic size frequency analysis (ELEFAN I).

The third growth parameter $\left(t_{0}\right)$ was determined using the empirical equation proposed by Pauly (1980). The longevity for each species was estimated by Taylor's equation (1962): $T_{\max }=3 / K+t_{0}$ where $K$ is the growth coefficient (annual) and $t_{0}$ the hypothetical age at length zero.

The recruitment pattern was obtained with ELEFAN II method (using the combined sex sizefrequency), which performs estimates with possible birthdates of individuals caught by retro calculus of the length frequencies, backward along the time axis. The recruitment patterns can be used to obtain objective information related to the length of the spawning season, as well as their relative magnitude (Pauly, 1987; Moreau \& Cuende, 1991).

\section{Natural mortality}

Estimates of natural mortality rates $(\mathrm{M})$ were obtained for each species (both sexes combined) through six different models: 1) Pauly's equation (1980), $\log \mathrm{M}=$ $-0.0152-0.279 \times \log L_{\infty}+0.6543 \times \log K+0.463 \times \log$ $\mathrm{T}$ where $\mathrm{T}$ is surface water temperature in ${ }^{\circ} \mathrm{C} ; 2$ ) Jensen's equation (1996), $\mathrm{M}=1.5(K)$ where $K$ is instantaneous growth coefficient; 3) Rugolo et al. (1998), $\mathrm{M}=3 / T_{\max \text { (years) }}$ where $T_{\max }$ is species longevity in years; 4) Hewitt \& Hoenig (2004), $M=4.22 / T_{\max }$ 
(years); Then et al. (2015) considering species longevity, 5) $\mathrm{M}=4.899 T_{\max }{ }^{-0.916}$ and taking into account growth parameter values 6) $\mathrm{M}=4.118 K^{0.73} L_{\infty}{ }^{-0.33}$. Average values of $\mathrm{M}$ and standard deviation (SD) for each species were obtained. The $\mathrm{M} / K$ ratio was estimated, and according to Beverton \& Holt (1956), the $\mathrm{M} / K$ ratio values should be from 1.5 to 2.5 .

\section{Length at first maturity}

Probability of mature females accumulated in each length interval was performed by calculating length at first maturity (FSM). Only were mature females in stages III, IV and V considered in the analysis, according to the maturation scale proposed by Barreiro (1986). The scale includes five steps, which agree to the macroscopic gonad aspect: I) immature, thin gonad confined to the abdomen, II) developing, thicker gonad, incipient cephalothoracic lobules, III) advanced maturity, very thick gonad, cephalothoracic lobules developed, IV) full maturity, gonad very thick and grainy, occupies all the cephalothorax, and V) spawned, gonad flaccid and thin.

The FSM was calculated using the logistic model: $P_{i}=1 /\left(1+\mathrm{e}^{-r(T L-L 50)}\right)$ where $P_{i}$ : mature female proportion; $r$ : slope of the logistic curve; $T L$ : observed total length interval; $L_{50}$ : average total length at which the individuals were found sexually mature (King, 2007). Parameter values in the logistic model were fitted using Newton's method and as function objective the sum of squares criterion (Neter et al., 1996).

\section{RESULTS}

During the two cruises, 67 fishing throws were performed in depths from 50 to $460 \mathrm{~m}$, and only in 21 of them, both rock shrimp species were caught. A total of 1,330 specimens were analyzed, of which $65 \%$ corresponded to $S$. ingentis and $35 \%$ to $S$. penicillata. The F:M ratio was 1.7:1 for $S$. ingentis and 1.5:1 for $S$. penicillata. The length/weight relationship (using both sexes), showed an isometric growth for $S$. ingentis with values of $a=0.000007, b=3.049$ (2.899-3.199, $P<$ 0.05 ), and a positive allometric growth for $S$. penicillata with values of $a=0.000002, b=3.341$ (3.233-3.448, $P$ $<0.05)$ according to the regression parameters.

\section{Latitudinal and bathymetric distributions}

Both species were distributed in the central region (off Kino Bay) and north of the Gulf of California (Fig. 1). Sicyonia ingentis had a presence in the southern part of Sonora (off Laguna El Tobari) in only one fishing throw. Both species were caught in the range from 124 to $338 \mathrm{~m}$ in depth (Fig. 2). However, major abundance

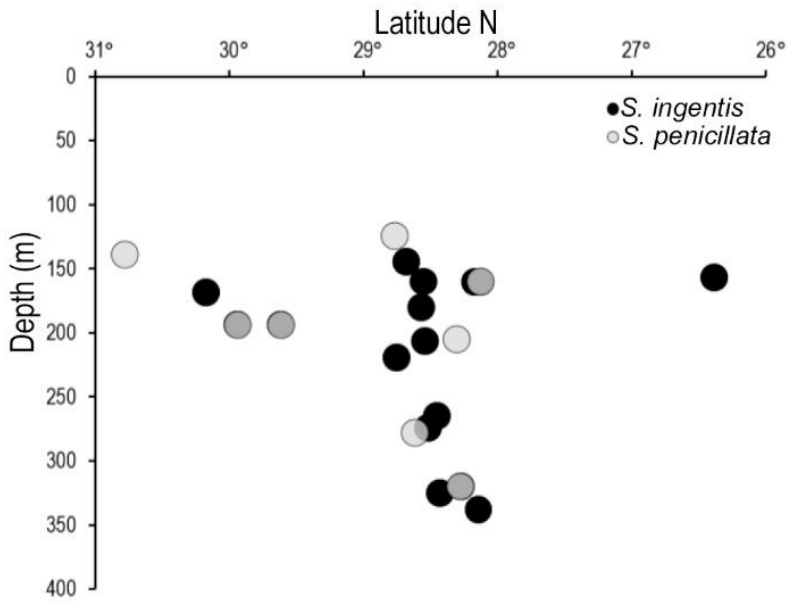

Figure 2. Bathymetric distribution of Sicyonia species $(S$. ingentis and $S$. penicillata) caught during two cruises in 2007 in the Gulf of California.

was obtained in depths from 195 to $325 \mathrm{~m}$ for $S$. ingentis and 205 to $320 \mathrm{~m}$ for $S$. penicillata.

TL of both species was in the range from 50 to 135 $\mathrm{mm}$ during the two cruises: S. penicillata was from 58 to $135 \mathrm{~mm}$ (mean $94.7 \pm 11.5 \mathrm{~mm}$ ), and $S$. ingentis from 58 to $130 \mathrm{~mm}$ (mean $93.5 \pm 9.96 \mathrm{~mm}$ ). The frequency distribution charts for both species show from one to three cohorts (age groups) on its size distribution (Figs. 3a-3b). Sicyonia ingentis did not show differences between sexes and sizes caught from 100 to $250 \mathrm{~m}$ and those from 251 to $350 \mathrm{~m}$, whereas a difference was observed for S. penicillata between lengths caught from 100 to $250 \mathrm{~m}$ (58-191 $\mathrm{mm} \mathrm{TL}$, average $97 \mathrm{~mm} \mathrm{TL})$ and those from 251 to $350 \mathrm{~m} \mathrm{(66-116} \mathrm{mm} \mathrm{TL,} \mathrm{average} 88$ mm TL) (Figs. 3c-3d).

\section{Individual growth and recruitment pattern}

The VBGM parameter values were $L_{\infty}=150.0 \mathrm{~mm} \mathrm{TL}$, $K=1.64$ annual and $t_{0}=-0.11$ years $^{-1}$ for $S$. ingentis and $L_{\infty}=150.0 \mathrm{~mm}$ TL, $K=1.55$ annual and $t_{0}=-0.12$ years $^{-1}$ for S. penicillata. The growth parameters obtained for these two species showed a moderate average growth, with theoretical longevity values of 1.71 years for $S$. ingentis and 1.81 years for S. penicillata. Estimated growth curves for both species in the Gulf of California are shown (Fig. 4).

The recruitment pattern showed a continuous period for both species with one recruitment peak of higher intensity from May to August for S. ingentis, with a major percentage value in June (12.0\%). S. penicillata had a higher recruitment percentage from November to May, with a maximum value in May (13.8\%) (Fig. 5).

\section{Natural mortality}

The Then et al. (2015) model showed higher M values, and the Rugolo et al. (1998) model indicated the lower 


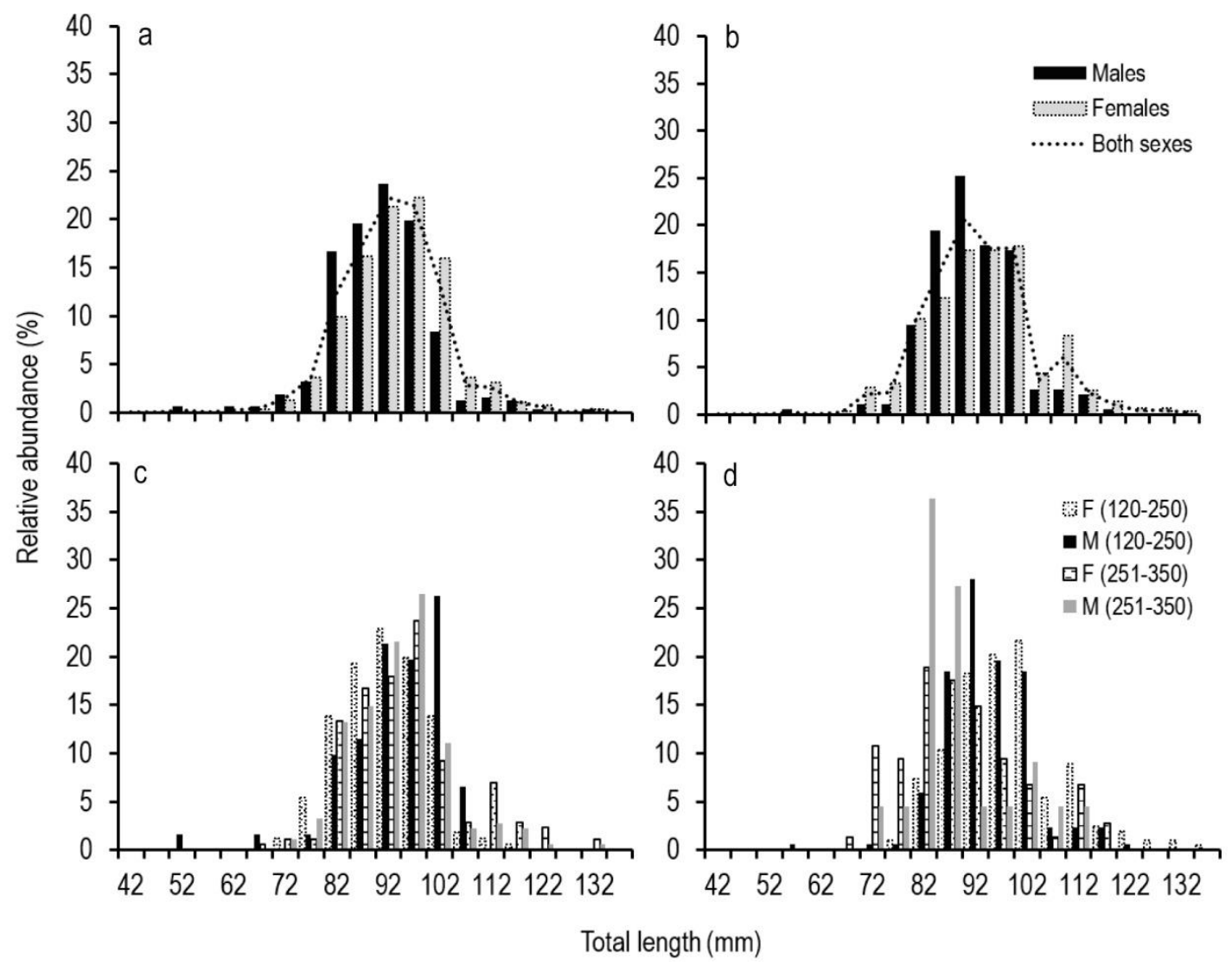

Figure 3. Length frequency distribution by sex of Sicyonia ingentis $(\mathrm{a}, \mathrm{c})$ and $S$. penicillata $(\mathrm{b}, \mathrm{d})$ by depth range during two cruises in 2007 in the Gulf of California.

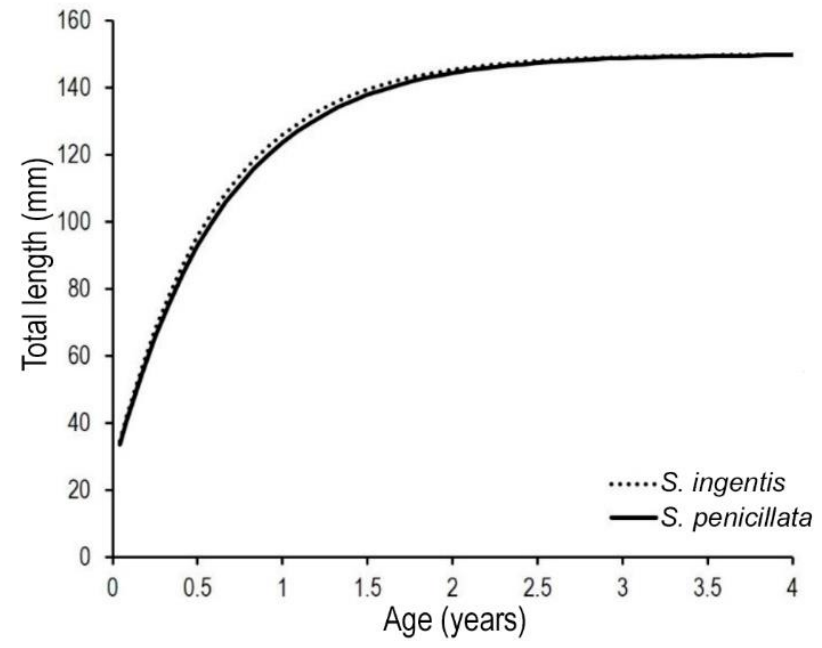

Figure 4. Individual average growth curve of the two rock shrimp species (Sicyonia ingentis and S. penicillata; both sexes) in the Gulf of California, Mexico.

ones. The M average value was $2.47 \pm 0.41$ for $S$. ingentis and $2.35 \pm 0.40$ for $S$. penicillata, considering the six models (Table 1).

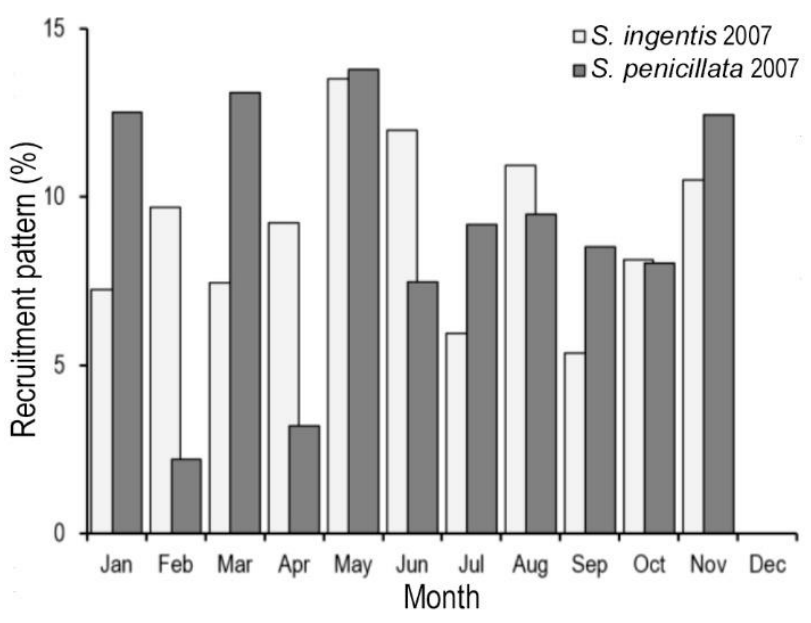

Figure 5. Retro-calculus of the perceptual recruitment pattern values for the two rock shrimp species (Sicyonia ingentis and S. penicillata; both sexes) in the Gulf of California, Mexico.

\section{Length at first maturity}

The $\mathrm{L}_{50}$ value estimated for $S$. ingentis was $94.33 \mathrm{~mm}$ TL $(\mathrm{a}=15.96 ; \mathrm{b}=0.169 ; r=0.169)$ with an adjusted value of $\mathrm{R}^{2}=0.984$; while $S$. penicillata $\mathrm{L}_{50}$ value was 


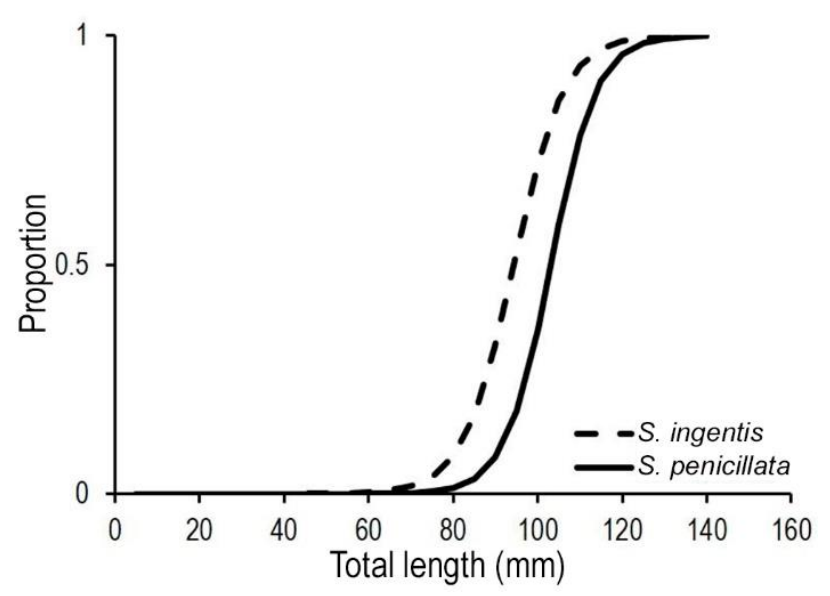

Figure 6. Length at first maturity sigmoidal curves shown, by the rock shrimp species (Sicyonia ingentis and $S$. penicillata; females), in the Gulf of California, Mexico.

$103.11 \mathrm{~mm}$ TL $(\mathrm{a}=19.19 ; \mathrm{b}=0.186 ; r=0.186)$ and $\mathrm{R}^{2}$ $=0.984$. The projected sigmoidal curves obtained by means of the logistic model for the two species, where the 0.5 probability point of length at first maturity was shown for each species (Fig. 6).

\section{DISCUSSION}

From the nine species of Sicyonia genus documented in the Gulf of California (Pérez-Farfante \& Boothe, 1981; Hendrickx, 1984b), only two species (S. ingentis and $S$. penicillata) were found in our study, covering from the Upper Gulf of California (Puerto Peñasco, Sonora) southward to Sonora (GC central region). The major abundance of both species was concentrated in the central part of the Gulf (front of Bahía Kino) at depths from 195 to $325 \mathrm{~m}$, on sandy and sandy mud substrates. López-Martínez et al. (2002b) mentioned that one of the principal fishing areas of $S$. penicillata in the GC was located off Bahía Kino, contributing with an average of $70 \%$ of the total catch of rock shrimp in the state of Sonora, with a greater exploitation pattern from February to April.

The depth records in our study agree with the catch records for $S$. ingentis reported by Hendrickx (1995) in the GC. However, it disagrees with those for $S$. penicillata, also reported by Hendrickx (1995), who mentioned this species was found in very shallow waters from 1 to $180 \mathrm{~m}$ in depth with major density from 30 to $80 \mathrm{~m}$. Likewise, Hendrickx (1995) reported these species inhabited a great variety of substrates (several types of sand and green clayey mud), finding the higher densities on sandy bottoms.

Population parameters are important to understand sustainable management strategies of the resources. Despite the lack of documented information on population dynamics of both rock shrimp species, more published information was found for S. penicillata. For the GC, Hendrickx (1995) reported TL of $160 \mathrm{~mm}$ for males and $180 \mathrm{~mm}$ for females of $S$. ingentis, both values higher than those obtained in our study (i.e., 130 $\mathrm{mm}$ TL for $S$. ingentis and $135 \mathrm{~mm}$ TL for $S$. penicillata).

For both rock shrimp species analyzed herein, females were more abundant than males, but the sex ratio of organisms smaller than $40 \mathrm{~mm}$ TL remains unknown because they could not be captured by trawls (mesh size of $40 \mathrm{~mm}$ ). Therefore, future experimental samplings should use trawl nets with a smaller mesh size to obtain information about small-sized individuals.

López-Martínez et al. (2002b) reported an isometric growth for S. penicillata off Bahía de Kino, which disagrees with the results obtained in this study (positive allometric growth $b>3$ ). This discrepancy could be due to sampling or measurement bias. Contrary to the results obtained for $S$. penicillata, $S$. ingentis had an isometric growth $(b=3)$, where a proportional increment was recorded between the total weight and total length. This finding agrees with those reported by Arreguín-Sánchez (1981) and LópezMartínez et al. (2002b) for species of the same genus. The $b$ values estimated for both species studied herein; however, were within the value interval reported for different penaeid shrimp species (Pauly et al., 1984).

Despite the few specimens used to estimate growth in this study, a wide size frequency of combined sexes was obtained for each species. Biases in growth parameter estimates, deriving from a narrow size frequency, can be generated. The results of the growth analyses of $S$. ingentis and $S$. penicillata indicated that both species had moderate individual growth $(K=1.60$ average). These results were similar to other studies (Arreguín-Sánchez, 1981; López-Martínez et al., 1999a). The growth parameters $L_{\infty}=150 \mathrm{~mm}, K=1.64$ for $S$. ingentis and $L_{\infty}=150 \mathrm{~mm}, K=1.55$ for $S$. penicillata estimated in this study showed moderate growth. However, growth was faster during the first year of age where both species grew around $80 \%$ of its total length, but then the growth curve turned asymptote, and in the last year almost no growth was observed (Fig. 4).

It is important to note that when using electronic length analysis methods to estimate growth parameters when biological information is sparse, several species life history assumptions need to be made. For example, assuming a constant population parameter system (Hilborn \& Walters, 1992; Jensen, 1996), especially in short life species such as rock shrimps, it could be hard to cover where the environment plays an important role 
Table 1. Estimated $\mathrm{M}$ values for the rock shrimp species in the Gulf of California by six different equations, $\mathrm{M} / K$ relation values, M average values and standard deviations (SD). For Then et al. (2015) equations, $T_{\max }$ based (a) and $L_{\infty}$ and $K$ based (b) estimates are shown.

\begin{tabular}{lcccc}
\hline \multirow{2}{*}{ Model } & \multicolumn{2}{c}{ Sicyonia ingentis } & \multicolumn{2}{c}{ Sicyonia penicillata } \\
\cline { 2 - 5 } & $\mathrm{M}$ & $\mathrm{M} / K$ & $\mathrm{M}$ & $\mathrm{M} / K$ \\
\hline Jensen (1996) & 2.46 & 1.5 & 2.33 & 1.5 \\
Pauly (1980) & 2.73 & 1.7 & 2.63 & 1.1 \\
Hewitt \& Hoenig (2004) & 2.47 & 1.5 & 2.33 & 1.4 \\
Rugolo et al. $(1998)$ & 1.75 & 1.1 & 1.65 & 1.0 \\
Then et al. $(2015)^{\mathrm{a}}$ & 3.00 & 1.8 & 2.84 & 1.8 \\
Then et al. $(2015)^{\mathrm{b}}$ & 2.42 & 1.5 & 2.32 & 1.8 \\
Mean \pm SD & $2.47 \pm 0.41$ & 1.51 & $2.35 \pm 0.40$ & 1.52 \\
\hline
\end{tabular}

in the stability of populations (Bauer \& Rivera-Vega, 1992). However, when a long time series that allow making more robust population parameters estimates are not available, a representative length frequency data set of the species is required to make initial approximations (Palomares \& Pauly, 2008). These first estimations should be done when there are populations that have an interest as a potential harvest resource (Quinn \& Deriso, 1999). This fact emphasizes the importance of studies, which uncover missing information in understanding the underlying population biology and for formulating future management strategies.

The longevity values estimated in this study were below the range (3-3.7 years) from those reported by López-Martínez et al. (2002b) for S. penicillata. The longevity values $\left(T_{\max }\right)$ obtained by Taylor's equation in this estimate were very similar between both rock shrimp species, 1.71 years for $S$. ingentis and 1.81 years for S. penicillata.

Natural mortality is a key parameter on species biology knowledge, but in population dynamics assessment, it is difficult to obtain a reasonable estimate of this value (Pauly, 1980). This parameter is related to basic biological aspects, such as reproduction, growth and longevity (Hewitt \& Hoenig, 2004; Then et al., 2015). It is also the most influential parameter for stock assessing, and the magnitude of $\mathrm{M}$ is related directly with population productivity.

Given the importance of $M$ value, it was necessary to determine the most suitable for the species. In this study, six models were selected to evaluate M; based on the results, the equation of Then et al. (2015) showed the highest $M$ values in both cases when growth parameter values were considered and when taking into account longevity values for the two rock shrimp species. The equation of Rugolo et al. (1998) showed the lowest $\mathrm{M}$ values among all six candidates in natural mortality models. An average M value was calculated using mathematical and biological information from all models. The $\mathrm{M}$ average value was 2.47 for $S$. ingentis and 2.35 for $S$. penicillata with $\mathrm{M} / K$ relationship of 1.51 and 1.52 respectively. On the other hand, Beverton $\&$ Holt (1956) mentioned that species $\mathrm{M} / K$ relationship should be in the range values from 1.5 to 2.5 . Therefore, the $\mathrm{M}$ values obtained by Then et al. (2015) (both solution cases) should be considered as appropriate since its relationship $\mathrm{M} / K$ was 1.8 for both species.

In the case of recruitment pattern (reproductive) of the two species, the indirect analysis performed can be used to obtain objective data related to the length of the spawning season, as well as its relative magnitude (Pauly, 1987). Sicyonia penicillata showed a continuous recruitment period (all year round) with a maximum from spring to summer. This behavior was similar to that found by López-Martínez et al. (2002b) for this same species. S. brevirostris has shown a massive spawning season from October to February, varying the starting and ending month, apparently in response to the length of the photoperiod (Cobb et al., 1973; Kennedy et al., 1977).

For this study, length at first maturity for females was $94.33 \mathrm{~mm}$ TL for $S$. ingentis and $103.11 \mathrm{~mm}$ TL for $S$. penicillata, which represented the first reproduction age at 29.2 and $38.6 \%$ of its theoretical longevity, respectively. It means that both species reached length at first maturity after 0.50 years of life $\left(62.9 \% L_{\infty}\right)$ for $S$. ingentis and 0.66 years $\left(68.7 \% L_{\infty}\right)$ for $S$. penicillata. With all this information, the two species could have a good capacity for redoubling their populations and reproducing more than once in their lives, which is important to consider in the near future in terms of fishery management of these two species.

As previously mentioned, until the last few years, individuals of the Sicyonia genus had been discarded from the great commercial penaeid shrimp catches in tropical and subtropical waters of the eastern Pacific and western Atlantic oceans due to their hard exoskele- 


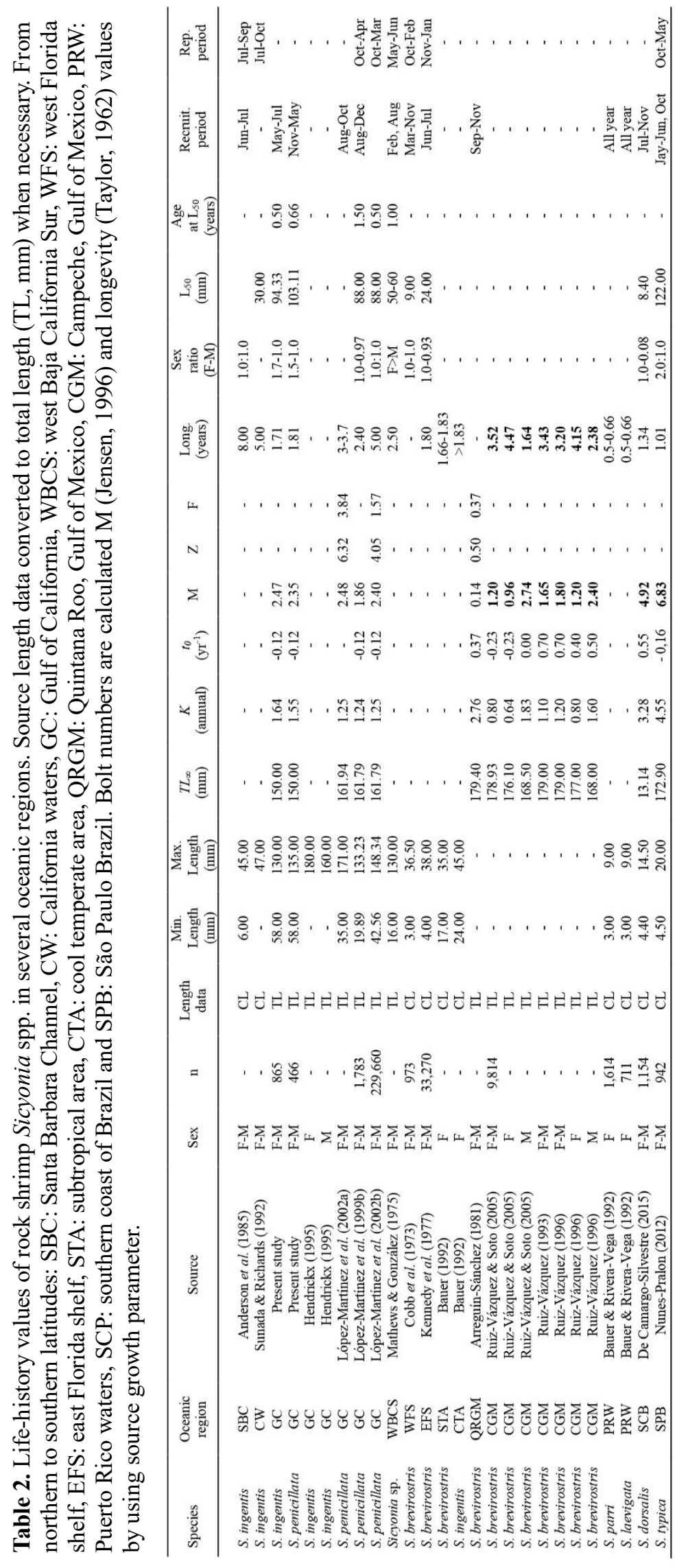


ton, commonly thought consumers and the food processing industry would reject it. However, the increase in shrimp demand motivated fishermen and business people to bring the largest species into the market, and now the demand has rapidly grown since some customers prefer rock shrimp rather than the species with thinner exoskeletons (Arreguín-Sánchez, 1981).

This work concentrated all available information for life parameter values of the genus Sicyonia in different oceanic regions, which is a result of an extensive literature search. For comparative intentions, reported growth parameter values were standardized to total length $(\mathrm{TL} \mathrm{mm})$ and annual base $\left(\right.$ years $\left.^{-1}\right)$ output values when necessary and possible (some studies reported carapace and tail lengths and monthly based growth coefficients). This standardization was performed using length relationship equations reported for each correspondent species of rock shrimp (Table 2).

The lack of several population parameters estimates for the genus Sicyonia was notable since those values have been obtained only for S. penicillata (LópezMartínez et al., 1999b, 2002b), S. dorsalis (see De Camargo-Silvestre, 2015), S. typica (Nunes-Pralon, 2012), and S. brevirostris (Arreguín-Sánchez, 1981; Ruíz-Vázquez, 1993，1996; Ruíz-Vázquez \& Soto, 2005). Some of those growth parameter values have been obtained repeatedly for a few rock shrimp species but in the same oceanic region as the Gulf of California, the Gulf of Mexico and the Caribbean Sea. The sparse or null growth values and other population dynamics parameters such as reproductive biology (first maturity length, reproductive period and sex ratio) for these species in other oceanic regions, where are also distributed, which did not allow making accurate geographic and demographic comparisons.

Bauer (1992) made a comparison of reproductive patterns among tropical, subtropical and cool temperate Sicyonia spp. reporting a continuous reproduction in the tropics with increased restriction of breeding season with an increase in latitude. Thus, a greater intensity of breeding effort appears to accompany the shorter breeding period associated with an increase in latitude at the tropical site, most females of all caridean species carried embryos during all months. With this respect, and due to the sparse life history information of the genus Sicyonia, robust inferences cannot be made; nevertheless, the empty values shown in Table 2 can be complemented in future studies.

Even though these species ( $S$. ingentis and $S$. penicillata) have shown a high potential for fishery development in the Central Gulf of California, according to López-Martínez et al. (1999a, 2002a), it is worth performing further studies in more extended time periods and exploring on board research cruises to allow determining biomass and spatial and temporal distribution all year round. Likewise, an analysis of the possible migration pattern that these species perform is considered highly desirable since it is still unknown to date.

\section{ACKNOWLEDGMENTS}

The authors would like to thank the SAGARPA-2003024 and SEMARNAT-2018- A3-S-77965 Project and staff of the Fisheries Laboratory of Centro de Investigaciones Biológicas del Noroeste, especially Eloisa Herrera Valdivia, for field and laboratory work, and Diana Fischer for editorial services in English.

\section{REFERENCES}

Anderson, S.L., Clark, W.H. \& Chang, E.S. 1985. Multiple spawning and molt synchrony in free spawning shrimp (Sicyonia ingentis: Sicyoniidae). Biological Bulletin, 168: 337-394.

Arana, P. \& Méndez, M. 1978. El género Sicyonia H. Milne Edwards, 1830 en el Pacífico Sur Oriental con observaciones biológicas sobre Sicyonia aliaffinis Burkenroad, 1938 (Crustacea: Decapoda: Penaeidae). Revista de Comisión Permanente del Pacífico Sur, 9: 19-40.

Arreguín-Sánchez, F. 1981. Diagnosis de la pesquería de camarón roca (Sicyonia brevirostris Stimpson, 1871) de Contoy, Q. Roo, México. Ciencia Pesquera, 1: 2141.

Barreiro, G.M.A. 1986. Estudio sobre la madurez y desove de Penaeus californiensis y Penaeus vannamei (Crustacea Decapoda, Penaeidae) en la costa sur de Sinaloa. Memorias del 1er. Intercambio Académico sobre Investigaciones en el Mar de Cortés. Hermosillo, Sonora México, pp 1-29.

Bauer, R.T. 1992. Repetitive copulation and variable success of insemination in the marine shrimp Sicyonia dorsalis (Decapoda: Penaeoidea). Journal of Crustacean Biology, 12: 153-160.

Bauer, R.T. \& Rivera-Vega, L.W. 1992. Pattern of reproduction and recruitment in two sicyoniid shrimp species (Decapoda: Penaeoidea) from a tropical seagrass habitat. Journal of Experimental Marine Biology and Ecology, 161: 223-240.

Beverton, R.J.H. \& Holt, S.J. 1956. A review of life spans and mortality rates of fish in nature, and their relation to growth and other physiological characteristics. In: Wolstenholme, G.E.W. \& O'Connor, M. The lifespan of animals. Ciba Foundation Symposium, Colloquia on Ageing. J. \& A. Churchill Ltda., London, Vol. 5: 142-180. 
Cobb, S.P., Futch, C.R. \& Camp, D.K. 1973. The rock shrimp, Sicyonia brevirostris Stimpson, 1871 (Decapoda, Penaeidae). Memoirs of the Hourglass Cruises, 3: 1-38.

Crosnier, A. 2003. Sicyonia (Crustacea, Decapoda, Penaeoidea, Sicyoniidae) de I'Indo-ouest Pacifique. Zoosystema, 2 (2): 197-348.

De Camargo-Silvestre, A.K.D. 2015. Dinámica populacional do camarón Sicyonia dorsalis (Crustacea: Penaeoidea) no litoral de Cananéia, sul do estado de São Paulo. Ph.D. Thesis, Universidade Estadual Paulista, São Paulo, 78 pp.

Estrada-Ramírez, A. \& Calderón-Aguilera, L.E. 2001. A range extension for Sicyonia penicillata on the western coast of Baja California, México. Crustaceana, 74(3): 317-320.

Freitas, A.J. 1984. The Penaeoidea of southeast Africa. V. The family Sicyoniidae. Investigational Report, South African Association for Marine Biological Research, 60: 1-12.

Gopalakrishnan, A., Rajkumar, M., Rahman, M.M., Sun, J., Antony, P.J., Venmathi-Maran, B.A. \& Trilles, J.P. 2014. Length-weight relationship and condition factor of wild, grow-out and 'loose-shell affected' giant tiger shrimp, Penaeus monodon (Fabricius, 1798) (Decapoda: Penaeidae). Journal of Applied Ichthyology, 30(1): 251-253.

Gould, S.J. 1966. Allometry and size in ontogeny and development. Biological Reviews of the Cambridge Philosophical Society, 41: 587-640.

Hendrickx, M.E. 1984a. The species of Sicyonia H. Milne Edwards (Crustacea: Penaeoidea) of the Gulf of California, México, with a key for their identification and a note on their zoogeography. Revista de Biología Tropical, 32: 279-298.

Hendrickx, M.E. 1984b. Distribution and abundance of Sicyonia penicillata Lockington 1879 in the Gulf of California, with some notes on its biology. Fishery Bulletin, 82(4): 715-720.

Hendrickx, M.E. 1995. Camarones. In: Fischer, W., Krupp, F., Schneider, W., Sommer, C., Carpenter, K.E. \& Niem, V. (Eds.). Guía FAO para la identificación de especies para los fines de la pesca. Pacífico centro-oriental. FAO, Rome.

Hendrickx, M.E. 1996. Los camarones Penaeoidea bentónicos (Crustacea: Decapoda: Dendrobranchiata) del Pacífico mexicano. Comisión Nacional para el Conocimiento y Uso de la Biodiversidad \& Instituto de Ciencias Marinas y Limnología. Universidad Autónoma de México, México D.F.
Hendrickx, M.E. 2002. New bathymetric record for the genus Sicyonia in the eastern Pacific. Oceanides, 17(2): 129.

Hewitt, D. \& Hoenig, J.M. 2004. Comparison of two approaches for estimating natural mortality based on longevity. Fishery Bulletin, 103(2): 433-437.

Hilborn, R. \& Walters, C.J. 1992. Quantitative fisheries stock assessment: choice, dynamics, and uncertainty. Reviews in Fish Biology and Fisheries, 2(2): 177-178.

Jensen, A.L. 1996. Beverton and Holt life history invariants result from optimal trade-off of reproduction and survival. Canadian Journal of Fisheries and Aquatic Sciences, 53: 820-822.

Kennedy, F.S., Crane, J.J., Schlieder, R.A. \& Barber, D.G. 1977. Studies of the rock shrimp Sicyonia brevirostris a new fishery resource on Florida's Atlantic Shelf. Florida Marine Research Publication, 27: 69 pp.

King, M.G. 2007. Fisheries biology, assessment, and management. Blackwell Scientific Publications, Oxford.

López-Martínez, J., Arreguín-Sánchez, F., MoralesAzpeitia, R. \& Salinas-Zavala, C. 2002a. Stock assessment and potential yield for the rock shrimp, Sicyonia penicillata, fishery of Bahia Kino, Sonora, México. Fisheries Research, 59(1-2): 71-81.

López-Martínez, J., Arreguín-Sánchez, F., NevárezMartínez, M.O., Morales-Azpeitia, R., Chávez-Ortiz, E.A. \& Alcántara-Razo, E. 2002b. Aspectos biológicos y pesqueros del camarón roca Sicyonia penicillata (Lockington, 1879) del golfo de California. In: Hendrickx, M.E. (Ed.). Contributions to the study of east Pacific crustaceans. Universidad Autónoma de México, México D.F.

López-Martínez, J., Chávez, E.A., Hernández-Vázquez, S. \& Alcántara-Razo, E. 1999a. Potential yield of a rock shrimp stock, Sicyonia penicillata of the northern Gulf of California. Crustaceana, 72(6): 581-590.

López-Martínez, J., García-Domínguez, F., AlcántaraRazo, E. \& Chávez, E.A. 1999b. Reproducción de camarón roca Sicyonia penicillata en Bahía Kino, Sonora, México. Revista de Biología Tropical, 47(12): 109-117.

Mathews, C.P. \& González, J.A. 1975. Potencial pesquero y estudios ecológicos de Bahía Magdalena 1. Las existencias de camarón con referencia especial al camarón de roca o camarón japonés. Ciencias Marinas, 2(1): 51-57.

Milne-Edwards, A. 1830. Extrait de recherches pour servir a l'histoire naturelle des crustacés amphipodes. Annales des Sciences Naturelles, 20: 353-399.

Moreau, J. \& Cuende, F.X. 1991. On improving the resolution of the recruitment patterns of fishes. Fishbyte, 9(1): 45-46. 
Neter, J., Kutner, M.H., Nachtsheim, C.J. \& Wasserman, W. 1996. Applied linear statistical models. McGrawHill, New York.

National Marine Fisheries Service (NMFS). 2003. Fisheries of the United States, 2002. Office of Science and Technology, Fisheries Statistics and Economics Division. [http://www.st.nmfs.nmfs.noaa.gov/st/commercial/index.haml]. Reviewed: 13 December 2018.

Nunes-Pralon, B.G. 2012. Dinâmica populacional do camarão pedra Sicyonia typica (Boeck), 1864) (Penaeoidea: Sicyoniidae) no litoral norte do estado de São Paulo. Ph.D. Thesis Biological Sciences, Instituto de Biociências de Botucatu, Universidade Estadual Paulista, São Paulo, 119 pp.

Ortmann, A.E. 1898. Crustacea, Malacostraca. In: Gerstäcker, A. \& Ortmann, A.E. (Eds.). Dr. H.G. Bronn's Klassen und Ordnungen des Thier-Reichs: wissenschaftlich dargestellt in Wort und Bild. C.F. Winter, Leipzig.

Palomares, M.L.D. \& Pauly, D. 2008. The growth of jellyfishes. In: Pitt, K.A. \& Purcell, J.E. (Eds.). Jellyfish blooms: causes, consequences, and recent advances. Springer, Dordrecht, pp. 11-21.

Patania, A. \& Mutlu, E. 2015. The occurrence of the nonnative species Sicyonia lancifer (Olivier, 1811) belonging to Sicyoniidae family is reported for the first time in the Mediterranean Sea. In the following paper, the distinguishing features of the species are provided. Mediterranean Marine Sciences, 1(5): 1-4.

Pauly, D. 1980. On the interrelation between natural mortality, growth parameters and mean environmental temperature in 175 fish stocks. ICES Journal of Marine Science, 39(2): 175-192.

Pauly, D. 1987. A review of the ELEFAN system for the analysis of length-frequency data in fish and aquatic invertebrates. ICLARM Conference Proceedings, 13: 7-34.

Pauly, D., Ingles, J. \& Neal, R. 1984. Application to shrimp stocks of objective methods for the estimation of growth, mortality and recruitment-related parameter from length-frequency date (ELEFAN I and II). In: Gulland, J.A. \& Rothschild, B.J. (Eds.). Peneid shrimp their biology and management. Fishing News Book, Farnham, pp. 220-234.

Pérez-Farfante, I. 1985. The rock shrimp genus Sicyonia (Crustacea: Decapoda: Penaeoidea) in the eastern Pacific. Fishery Bulletin, 83: 1-79.

Pérez-Farfante, I. \& Boothe, B.B. 1981. Sicyonia martini, a new rock shrimp (Decapoda: Penaeoidea) from the American Pacific. Journal of Crustacean Biology, 1: 424-432. doi: 10.1163/1937240X81X00492

Pérez-Farfante, I. \& Kensley, B. 1997. Penaeoid and sergestoid shrimps and prawns of the World. Key and diagnoses for the families and genera. Memoires du Museum National d'Histoire Naturelle, 175: 1-233.
Powell, D.G. 1979. Estimation of mortality and growth parameters from the length frequency of a catch. Rapports et Proces-Verbaux des Réunions du Conseil International pour l'Exploration de la Mer, 175: 167169.

Quinn, T.J. \& Deriso, R.B. 1999. Quantitative fish dynamics. Oxford University Press, Oxford.

Ricker, W.E. 1975. Computation and interpretation of biological statistics of fish populations. Bulletin of the Fisheries Research Board of Canada, 191: 1-382.

Rugolo, L.J., Knotts, K.S., Lange, A.M. \& Crecco, V.A. 1998. Stock assessment of Chesapeake Bay blue crab (Callinectes sapidus Rathbun). Journal of Shellfish Research, 17(3): 906-930.

Ruíz-Vázquez, R. 1993. Evaluación de los parámetros de crecimiento de la población de camarón de roca Sicyonia brevirostris en la zona de Contoy Quintana Roo. Instituto Nacional de Pesca, Coyoacán, 26 pp.

Ruíz-Vázquez, R. 1996. Evaluación de los parámetros de crecimiento y mortalidad de la población de camarón de roca Sicyonia brevirostris en la zona de Contoy Quintana Roo. Tesis de Licenciatura, Instituto Nacional de Pesca, Coyoacán, 48 pp.

Ruíz-Vázquez, R. \& Soto, L. 2005. Parámetros de crecimiento de Sicyonia brevirostris en Contoy, Quintana Roo, México. Revista de la Sociedad Mexicana de Historia Natural, 2(1): 127-140.

Shanis, R.C.P., Akhilesh, K.V., Ganga, U. \& Pillai, N.G.K. 2013. New distribution record of the rock shrimp, Sicyonia parajaponica Crosnier, 2003 from Indian waters. Indian Journal of Fisheries, 60(1): 131132.

Sparre, P. \& Venema, S.C. 1995. Introducción a la evaluación de recursos pesqueros tropicales. Parte 1: manual. FAO Fisheries Technical Paper, 306/1: 376 pp.

Stiles, M.L., Harrould-Kolieb, E., Faure, P., Ylitalo-Ward, H. \& Hirshfield, M.F. 2007. Deep sea trawl fisheries of the Southeast US and Gulf of Mexico: rock shrimp, royal red shrimp, calico scallops. Oceana, $18 \mathrm{pp}$.

Sunada, S.J. \& Richards, B.J. 1992. Ridgeback prawn. In: Leet, W.S., Dewees, C.M. \& Haugen, C.W. (Eds.). California's living marine resources and their utilization. Sea Grant Extension Program, Department of Wildlife and Fisheries Biology, University of California, pp. 11-12.

Taylor, C.C. 1962. Growth equations with metabolic parameter. ICES Journal of Marine Science, 27(3): 270-286.

Then, A.Y., Hoenig, J.M., Hall, N.G. \& Hewitt, D.A. 2015. Evaluation the performance of empirical estimator of natural mortality rate using information on over 200 fish species. ICES Journal of Marine Science, 72(1): 81-82. 
Thompson, S.K. 1991. Adaptive cluster sampling: designs with primary and secondary units. Biometrics, 11031115.

Von Bertalanffy, L. 1938. A quantitative theory of organic growth (inquiries on growth laws II). Human Biology, 10: 181-213.

Received: 21 July 2018; Accepted: 27 March 2019
Wetherall, J.A., Polovina, J.J. \& Ralston, S. 1987. Estimating growth and mortality in steady-state fish stocks from length-frequency data. ICLARM Conference Proceedings, 13: 53-74.

Zar, J.H. 1984. Biostatistical analysis. Prentice Hall, New Jersey. 